\title{
The Opportunity of Intellectual Property On Small and Medium-Scale Enterprises in Malang Raya Region
}

\author{
Maftuchah $^{\# 1}$, Aris Winaya ${ }^{\# 2}$, Sofyan Arief ${ }^{\# 3}$ \\ \# The Center for Intellectual Property (SENTRA HKI), University of Muhammadiyah Malang, \\ Malang, Indonesia \\ ${ }^{1}$ maftuchaheumm.ac.id \\ ${ }^{2}$ winaya@umm.ac.id \\ ${ }^{3}$ sofyan@umm.ac.id
}

\begin{abstract}
The small and medium-scale enterprises (SMEs) has significantly contributed to economic aspect and overcoming the unemployment and employment issues in Indonesia. SMEs mainly refers to a productive business that stands alone, carried out by an individual and/or business entity with particular criteria. Malang Raya region is covering included of Batu City, Malang Regency, and Malang City and the one of an area that develops fast enough in East Java Province, including in the industrial sectors. However, the amount of Intellectual Property Rights (IPR) application was still low compared to the SMEs number. The objective of this study was to get the opportunity of IPRs potency of SMEs in Malang Raya region. In the long term it is expected to encourage the research and development program which has orientation to the IPRs of SMEs and gives an assistance to SMEs to obtain the IPRs protection. The period of data collection was from 2015 to 2016. The sample was conducted on 90 SMEs in Malang Raya region by primary and secondary data. The data was obtained by using field observation method with respondents participatory, in-depth interview, documentary, and purposive sampling to each area. The result of this study showed that most of SMEs in Malang Raya area was the industry of processed food $(54.40 \%)$ with $47.77 \%$ of the market area was on national scale and $40 \%$ was on East Java regional market and the rest was local market. The $68.89 \%$ of SMEs did not have any IPRs problem, but $31.11 \%$ of them encountered some issues, especially on the trademark. The data showed that $12.23 \%$ of SMEs in Malang Raya region have patent opportunity, $42.22 \%$ copyright, $\mathbf{7 . 7 8 \%}$ industrial design and $91.11 \%$ trademark which was need to IPR guidance
\end{abstract}

Keywords — copyrights, IPRs, SMEs, patent, Malang Raya

\section{INTRODUCTION}

Micro, Small and Medium-scale Enterprises has been an important part in Indonesian economic. It is estimated that there are around 1,361,129 of small and medium-scale business in Indonesia [1]. The number of SME is bigger than the large-scale industry and it has high contribution toward the economic sector. The SME keeps growing to achieve its main goal that is to develop national economic sector. The SME is the business enterprise of majority Indonesian and has developed in almost all parts of the nation.

The pattern of SME closely related to human life aspects, especially food, clothing and housing. SME has an active role in food sector such as agricultural-husbandry, agricultural processing, culinary, etc. The SME sector provide a great contribution in economic sector, overcome the unemployment and labor issues. Besides that, the SME has a high contribution on Gross Domestic Product (PDB) and more than half of our economic sector is supported by the SME [2]. In macroeconomics analysis, the SME has a strategic role in national income and to reduce the unemployment rate, in accordance with the Regulation no. 20 year 2008-chapter III article V which says "To increase the role of small, micro and medium-scale enterprise in regional development, creating job opportunity, income distribution, economic growth and poverty alleviation".

There has been various problem emerged along with the vibrant attempt of the government in forming the SME. Some of the problems are: 1) the SME's product tend to have less power in competing with foreign product, 2) SME tends to not think yet about improving its product design and marketing capability, 3) SME tends to be less innovative in product design; 4) SME is less adaptable to the increasingly dynamic market which tends to more attracted to new and innovative products; 5) SME consists of mostly home industry enterprises which have limited market network. Survey result obtained from Central Statistics Body 
identifies various weaknesses and issues faced by SME based on its priority, they are: a) lack of capital, b) difficulties in marketing, c) a tight business competition, d) difficulties in raw material provision, e) lack of skill, f) lack of managerial skill, and $(\mathrm{g})$ lack of managerial knowledge especially finance and accounting [3].

Currently, as the role of SME is getting more important, there is also a need to find solution in overcoming issues to handle product with less competitive value, it needs to give counselling on better product innovation so that the business people can create latest innovation. The SME is closely related to Intellectual Property Right (IPR). The IPR potential is closely related to the SME performance, however not many SME realize the advantage of IPR as a business asset. Every product resulted from the business, applied technology, design of each product, trademark application, or brand service for product marketing are all related to IPR.

Innovation skill is one of characteristics that is important in running any business [4]. Without innovation, any business will not develop as customers demand is constantly changing. Customers do not always consume the same product. They will search for another product from other companies that can fulfill their need and expectation. Therefore, companies need non-stop innovation to keep the business run well. Development in various sectors will not be achieved without any innovation culture from the society. Creativity and innovation culture will only can grow and develop well in a society that appreciate, uphold and protect the IPR. Innovation is the ability to apply creativity in solving problem and chance to improve and enrich the life [5]. Innovation is the idea, practice or object which are considered as new by other people or user unit [6]. Innovation is important because: 1). Rapid change of technology is in line with the new product release, process and service from the competitors, 2). The effect of environment change toward product life cycle is getting shorter, 3) Smart and demanding consumers in fulfilling the needs, 4) The rapidly changed market and technology makes brilliant ideas are easily being imitated, 5) Innovation can create more rapid development, increase market segment and create a better corporate position [7].

Indonesia has signed the AFTA (Asean Free Trade Area) agreement in which all country members agreed to abolish all customs and excise. AFTA is both chance and challenge for Indonesia. As a chance, being AFTA member requires the government to protect, educate and facilitate the society in preparing themselves to face the AFTA, one of which by IPR protection for the people, especially SME. Indonesia government realizes the importance of intellectual property for the SME. Therefore, the government through various effort tries to support the SMEs to actively register to the IPR.

This study aimed at finding out the SMEs' intellectual property potential in Malang Raya region. For the long run, this activity is expected to support other IPR-oriented study in SME and to support the SME in gaining the IPR protection.

\section{METHODS}

This study was conducted in 2016, in Malang Raya region. Data were obtained through society who ran their business in SME scale by site inspection using survey method. There were 90 SMEs as sample taken from 3 areas, namely Malang regency of 30 SMEs, Malang municipality of 30 SMEs and Batu Administrative city of 30 SMEs. The secondary data was in the form of relevant documents, obtained from local industrial affair agency. The field observation was conducted by purposive sampling toward randomly selected industry per area with initial data obtained from the local Industrial Affair agency in each regency/municipality.

The observation was conducted in several stages, namely: 1) administrative and license preparation, 2) information on SME from industrial affair agency, 3) questionnaire design, 4) questionnaire multiplication, 5) Field survey, 6) Data analysis and interpretation, 7) Observation report. Observation survey was conducted on: 1) type of SME based on product, 2) Market area for SME's product, 3) The SME's intellectual property potential, 4) Ever / never have any issue regarding IPR, 5) The type of IPR issue(s) that ever occured, and 6) The urgency of IPR supervision according to the SME's perception. Data were displayed in the form of 
number and percentage of each parameter being observed

\section{RESULT AND DISCUSSION}

Table 1 shows the percentage of type of SME is Malang Raya region. The data shows that 54.44\% SMEs in Malang is in the processed food industry (variety of fruity chips, tempe chips, fruit-based food, juice, grass juice, herbal product, candy,etc) and $18.89 \%$ is in the culinary field (food vendors/restaurant, café, snacks, etc). \%. SME that works in agricultural field reaches $11.11 \%$. The SMEs in agricultural field includes: rice and corn fields, vegetables, fruits, houseplant, houseplant seeds and crops seeds. The SMEs that work in fashion field includes clothing store, batik store, Muslim garment, etc reaches $8.89 \%$, while the SMEs that work in craft field reaches $6.67 \%$.

SMEs basically refer to an independent productive business run by an individual, and/or individual entities or an agency with their respective criteria. The criteria different of small and medium enterprises is based on the net worth and annual gross sales (Regulation number 20 year 2008). The regulation clearly set the different, both from asset and revenue, of small and medium enterprises. However, in overall, the SMEs has important role in developing the national economic. SMEs in processed food and culinary is very dominant in Malang Raya region, this is due to the Malang Raya region (especially Batu administrative city) has been developing as tourism city, while Malang itself is a city of education, both reasons invite plenty tourists and university students.

TABLE I.

PERCENTAGE OF SMALL-MEDIUM ENTERPRISES TYPE IN MALANG RAYA REGION

\begin{tabular}{|l|c|c|c|c|c|}
\hline \multirow{2}{*}{ SME Type } & \multicolumn{3}{|c|}{ Region } & \multicolumn{2}{c|}{ Malang Raya } \\
\cline { 2 - 6 } & Batu & $\begin{array}{c}\text { Malang } \\
\text { Regency }\end{array}$ & $\begin{array}{c}\text { Malang } \\
\text { Municipality }\end{array}$ & Total & Percentage \\
\hline Processed food & 18 & 16 & 15 & 49 & 54.44 \\
\hline Craft & 1 & 2 & 3 & 6 & 6.67 \\
\hline $\begin{array}{l}\text { Agricultural / } \\
\text { Husbandry }\end{array}$ & 2 & & - & 10 & 11.11 \\
\hline Fashion & 3 & - & 5 & 8 & 8.89 \\
\hline Culinary & 6 & 4 & 7 & 17 & 18.89 \\
\hline Total & 30 & 30 & 30 & 90 & 100 \\
\hline
\end{tabular}

TABLE II.

PRODUCT MARKETING AREA OF SMALL-MEDIUM ENTERPRISES IN MALANG RAYA REGION

\begin{tabular}{|l|l|l|l|l|l|}
\hline \begin{tabular}{c} 
Product \\
Marketing \\
\multicolumn{1}{|c|}{ Area }
\end{tabular} & \multicolumn{3}{|c|}{ Region } & \multicolumn{2}{c|}{$\begin{array}{c}\text { Malang Raya } \\
\text { Region }\end{array}$} \\
\cline { 2 - 6 } & Batu & $\begin{array}{c}\text { Malang } \\
\text { Regency }\end{array}$ & $\begin{array}{c}\text { Malang } \\
\text { Municipality }\end{array}$ & Total & $\%$ \\
\hline $\begin{array}{l}\text { Malang } \\
\text { Raya region }\end{array}$ & 5 & 9 & 6 & 20 & $\begin{array}{l}22.2 \\
1\end{array}$ \\
\hline $\begin{array}{l}\text { Regional } \\
\text { (East Java) }\end{array}$ & 12 & 8 & 16 & 36 & $\begin{array}{l}40.0 \\
0\end{array}$ \\
\hline $\begin{array}{l}\text { National } \\
\text { (Indonesia) }\end{array}$ & 12 & 13 & 8 & 33 & $\begin{array}{l}36.6 \\
8\end{array}$ \\
\hline International & 1 & 0 & 0 & 1 & 1.11 \\
\hline Total & 30 & 30 & 30 & 90 & 100 \\
\hline
\end{tabular}

Tabel 2 Shows the product marketing area of small-medium enterprises in Malang Raya region. From the data, it is obtained that the highest marketing area (40\%) is on regional level (East Java). National marketing reached $36.68 \%$, while the marketing in Malang Raya region reached $22.21 \%$ and the international marketing is only

\section{$1.11 \%$}

The product marketing catchment area (Tabel 2) shows that the marketing area of small and medium-scale enterprise is actually very wide. Therefore, the IPR is very necessary because when a good is sold without IPR protection, it will likely have a potential to be recognized as a product of other industry.

TABLE III.

DATA ON POTENTIAL OF EACH INTELLECTUAL PROPERTY RIGHTS REGIME ON SMALL AND MEDIUM ENTERPRISES IN MALANG RAYA REGION

\begin{tabular}{|l|l|l|l|l|l|}
\hline $\begin{array}{l}\text { Potential of } \\
\text { Intellectual } \\
\text { Property of } \\
\begin{array}{c}\text { Each } \\
\text { Regime }\end{array}\end{array}$ & \multicolumn{3}{|c|}{ Area } & \multicolumn{2}{c|}{$\begin{array}{c}\text { Malang Raya } \\
\text { region }\end{array}$} \\
\cline { 2 - 6 } & Batu & $\begin{array}{l}\text { Malang } \\
\text { Regency }\end{array}$ & $\begin{array}{c}\text { Malang } \\
\text { Municipality }\end{array}$ & Total & $\%$ \\
\hline Brand & 17 & 16 & 1 & 34 & $\begin{array}{l}37.7 \\
8\end{array}$ \\
\hline Patent & 3 & 1 & 7 & 11 & $\begin{array}{l}12.2 \\
2\end{array}$ \\
\hline $\begin{array}{l}\text { Industrial } \\
\text { Design }\end{array}$ & 1 & 2 & 4 & 7 & 7.78 \\
\hline Copyright & 9 & 11 & 18 & 38 & $\begin{array}{l}42.2 \\
2\end{array}$ \\
\hline Total & 30 & 30 & 30 & 90 & 100 \\
\hline
\end{tabular}

Table 3 above shows the potential of each intellectual property rights (IPR) regime of SME in Malang Raya region. IPR potential in the form of 
copyrights is very dominant $(42.22 \%)$. Of 90 small industries surveyed, 34 industries $(37.78 \%)$ have the potential for Brand registration, 11 industries $(12.22 \%)$ have patent potential, and 7 industries $(7.78 \%)$ have industrial design potential.

In general, IPR is divided into two categories, namely Copyright and Industrial Property Rights. Industrial Property Rights involve: Patent, Trademark, Industrial Design, Integrated Circuit Layout Design, Trade Secret, and Plant Varieties. Patent is IPR regime related to technology. Trademark is a symbol in the form of image, name, word, letters, numbers, color arrangement, or combination of those elements, which have differentiating power and is used in the trade of goods or services [8]. Industrial Design is a creation of shape, configuration, or line / color composition, or line and color, or combination of those in the form of three dimensional or two-dimensional figure that gives aesthetic impression and realized in three dimensional or two-dimensional pattern in order to generate products, goods, industrial commodities, or handicrafts [9]. Meanwhile, Trade Secret is exclusive information in technology and/or business, with economic values due to its benefit in business activities, and kept confidential by the owner of Trade Secret [10].

To determine the need of IPR protection of existing SME, then the first thing to understand is the existing potential in the SME's business activity. Globally, the potentials of IPR in SME's business activity are Copyright, Trademark/service, Industrial Design, and Patent/simple patent. Definitely, the required IPR protection is not always the same in every business activity. Copyright is significantly dominant in Handicraft, Fashion, and Processed-food Industries. The high potential of copyrights in Malang is due to the rapid growth in the area of Malang.

Various SME issues related to IPR protection, such as: 1) High IPR registration fee, either for initial registration, extension (such as trademark) or maintenance fee (such as in patent), 2) The lack of technology access in SME, so the applied technology is generally inadequate for patent registration, 3) Narrow market access, 4) Quality of human resource, not yet aware of the importance of IPR, 5) The need of serious attention of the government and sustainable efforts to assist SME in IPR ownership and protection, 6) Unorganized and unsustainable assistance.

TABLE IV

ISSUES OF IPR IN SMALL MEDIUM ENTERPRISES IN MALANG RAYA REGION

\begin{tabular}{|c|c|}
\hline $\begin{array}{c}\text { IPR issues } \\
\text { have ever occurred }\end{array}$ & $\begin{array}{c}\text { IPR issues } \\
\text { have not occurred yet }\end{array}$ \\
\hline $28(31.11 \%)$ & $62(68.89 \%)$ \\
\hline
\end{tabular}

Table 4 shows that as much as $31.11 \%$ small medium enterprises in Malang Raya region have ever experienced IPR issues. The issues occur mainly in trademark violation between similar companies, as much as $7.78 \%$ (Table 5). In this free trade era, intellectual right protection in SME is an inevitable need. IPR is one of the important aspects for SME to conduct business development and to provide high economic value. In the meantime, the need for IPR ownership for SME aims to prevent unhealthy competition among fellow business actors, both domestically and abroad. IPR ownership for SME is able to improve the added value, productivity, work quality, and to provide competitiveness for the SME per se.

TABLE V

TYPE OF IPR ISSUES IN SMALL MEDIUM ENTERPRISES IN MALANG RAYA REGION

\begin{tabular}{|l|l|}
\hline Aspect & Amount (percentage) \\
\hline Trademark & $7(7.78)$ \\
\hline Patent & - \\
\hline Industrial Design & $1(1.11)$ \\
\hline Copyright & $1(1.11)$ \\
\hline Total & 10 \\
\hline
\end{tabular}

Free competition has been widely applied both to large and Small Medium Enterprises. The impact of free trade would be significant, especially for SME. SME must have the readiness and strength to survive and compete in free trade era. SME needs not only capital, marketing, capable human resource, and intellectual property as the assets. Intellectual property right ownership is an important aspect for the strengthening of SME. SME has a choice to register or not the intellectual property of its product or service. Both aspects have their own consequences. The issue of intellectual property ownership has a practical impact for SME. 
The issues above need to be solved by SME in order to survive in free trade era. SME strengthening through intellectual property ownership is required so that SME could survive and compete with other SMEs both domestically and abroad.

TABLE VI

THE AMOUNT AND PERCENTAGE OF SMALL INDUSTRIES THAT NEED IPR ASSISTANCE IN MALANG RAYA REGION

\begin{tabular}{|l|c|c|c|c|}
\hline \multicolumn{3}{|c|}{ Region } & \multicolumn{2}{c|}{ Malang Raya Region } \\
\hline Batu & $\begin{array}{c}\text { Malang } \\
\text { Regency }\end{array}$ & $\begin{array}{c}\text { Malang } \\
\text { City }\end{array}$ & Total & Percentage \\
\hline 7 & 1 & 9 & 17 & 18.89 \\
\hline
\end{tabular}

As much as $18.89 \%$ small medium enterprises in Malang Raya Region mentioned they need IPR assistance while the majority of SME said the contrary (Table 6). IPR protection is more indispensable for SMEs because: 1) More than 90\% companies in various economic activities is SME, which significantly contributes to employees absorption, trade, investment, and economic growth, 2) SME is proven to be one of the innovation booster due to the abundant ideas that can be accommodated by IPR, 3) In economic management, related to new knowledge, intangible assets, that involves innovative ideas and centralistic information pertaining to business assets, 4) IPR is an asset with high economic value.

Generally, the outcome of this activity shows that IPR potential in small medium industries in Malang Raya region is considered high. However, the existing SME generally do not understand the importance of Intellectual Property Right registration for the company's development and sustainability. In addition to low understanding, relatively expensive registration fee and IPR benefit have not reached small industries community, thus the interest to register industrial property right is still very low. The government has attempted to raise the awareness of IPR on the importance of IPR, especially in creative industry aspect. This aims to protect IPR so that it grows rapidly.

The government, through its policies or regulations, has accommodated SME in IPR handling. IPR registration fee for SME has been set lower than non-SME businesses. The government has also strived to provide various facilities. However, there are still many SMEs facing difficulties in IPR registration.

\section{CONCLUSIONS}

The result of this study showed that most of SMEs in Malang Raya region were processed food industries $(54.40 \%)$ with $47.77 \%$ of the market area was on national scale and $40 \%$ was on East Java regional market and the rest was local market. The $68.89 \%$ of SMEs have not on IPRs problem, but $31.11 \%$ of them have the problem, especially on the trademark. The data showed that $12.23 \%$ of SMEs in Malang Raya region have patent opportunity, $42.22 \%$ copyright, $7.78 \%$ industrial design and $91.11 \%$ trademark which was need to IPR guidance.

\section{ACKNOWLEDGMENT}

Gratitude is addressed to the Board of Directors Muhammadiyah University of Malang that has fully supportive in providing research fund through the Excellence Research Program of Study Center for Intellectual Property Right Centre- Fiscal Year of 2016.

\section{REFERENCES}

[1] Kementerian Negara Koperasi dan UKM [State Ministry of Cooperations and SMEs], (2009). Undang-Undang Usaha Mikro Kecil dan Menengah (UMKM) UU RI No.20 Tahun 2008 [Act of Micro, Small and Medium Enterprises (MSMEs) of Republic of Indonesia Act No. 20, 2008]. Jakarta: Sinar Grafika.

[2] M.W.B. Utami, (2020). "Pemanfaatan Desain Industri bagi Pengembangan Usaha Mikro, Kecil dan Menengah : Antara Kenyataan dan Harapan" [Utilization of Industrial Design for Micro, Small and Medium Business Development: Between Reality and Expectations] Media HKI, Direktorat Jenderal Hak Kekayaan Intelektual, Kementerian Hukum dan HAM- RI, VII/01 : 13-15. 2010 www.dgip.go.id. Accessed on 12 January 2013.

[3] E. Hidayati, (2014). "Komersialisasi Hak Kekayaan Intelektual (HKI) melalui Lisensi". Workshop Lisensi dan Komersialisasi HKI. Universitas Negeri Yogyakarta. 29 Agustus 2014. 22 p.

[4] P. Larsen and A. Lewis. (2007). "How Award-Winning SMEs Manage The Barriers to Innovation", Creativity and Innovation Management page: $142-151$.

[5] Suryana, (2003). "Kewirausahaan, Pedoman Praktis, Kiat dan Proses Menuju Sukses" [Entrepreneurship, Practical Guidelines, Tips and Processes Towards Success], Edisi Revisi, Jakarta: Salemba Empat..

[6] G. Hills, C. Hultman and M. P Miles, (2008). "The Evolution and Development of Entrepreneurial Marketing Journal of Small Business Management 46 (1):99 - 112, January.

[7] H.T. Keeh, M. Nguyen and Ping, (2007). "The Effects of Entrepreneurial Orientation and Marketing Informationon the Performance of SMEs", Journal of Business Venturing, page: 592-611.

[8] Undang-Undang Republik Indonesia No 14 Tahun 2001 tentang Paten. [Republic of Indonesia Act No.14, 2001, about Patent].

[9] Undang-undang RI No.20, tahun 2008. Usaha Mikro, Kecil dan Menengah. Departemen Koperasi RI. [Republic of Indonesia Act No. 20, 2008, Micro, Small and Medium Enterprises, Department of Cooperations, Republic of Indonesia], Accessed 21 November 2015. 
[10] Undang-Undang Hak Kekayaan Intelektual. Direktorat Jenderal Hak Kekayaan Intelektual. Kementerian Hukum dan HAM RI. [Act of Intellectual Property Rights, Directorate General of Intellectual
Property Rights, Ministry of Law and Human Right, Republic of Indonesia], 